\title{
SELECTIVE CHANGES IN EXPRESSION OF INTEGRIN $\alpha$-SUBUNITS IN THE INTESTINAL EPITHELIAL CACO-2 CELLS UNDER CONDITIONS OF HYPOXIA AND MICROCIRCULATION
}

Maltseva DV ${ }^{1}$, Poloznikov $\mathrm{AA}^{1}$, Artyushenko VG ${ }^{2}$

${ }^{1}$ National Research University Higher School of Economics, Moscow, Russia

${ }^{2}$ Art photonics $\mathrm{GmbH}$, Berlin, Germany

\begin{abstract}
Intestinal epithelial cells are constantly exposed to physiologically hypoxic environment. The further reduction of tissue oxygen delivery may result in the intestinal epithelial cells function impairment, being a sign of active inflammation. The cell culture conditions are important when performing in vitro studies, since those may affect the cells' properties. The study was aimed to assess the integrin receptor expression in the human colon adenocarcinoma Caco-2 cell line when simulating both the cobalt (II) chloride-induced hypoxia and microcirculation. Transcriptome analysis revealed the significantly increased expression of ITGA2 and ITGA5 genes, encoding $\alpha 2$ and $\alpha 5$ integrin subunits, under hypoxic conditions, as well as the reduction of ITGA5 during incubation in the microfluidic chip. The expression of $\beta$-subunits did not change. Analysis of microRNA transcriptomes revealed the decreased expression of hsa-miR-766-3p and hsa-miR-23b-5p microRNA. One of the validated targets for both microRNAs is the ITGA5 mRNA. It has been shown that microcirculation makes it possible to bring the intestinal epithelial cell culture conditions closer to physiological conditions. The possible biological significance of the detected integrin expression profile alterations and the role of microcirculation have been discussed.
\end{abstract}

Keywords: hypoxia, integrins, microfluidic chip, miRNA, mRNA, proteome, gut microbiota, Caco-2

Author contribution: Maltseva DV — working with cultured cells, molecular biology research, data analysis, manuscript writing; Poloznikov AA — proteomic and transcriptomic analysis data processing, bioinformatics analysis, functional analysis of genes, statistical analysis, manuscript writing, study management; Artyushenko VG — interpreting the study results, manuscript reviewing.

Acknowledgement: the authors express their appreciation to the Center for Collective Use "Human Proteome" (IBMC) for the opportunity to use the equipment for proteome analysis, and to the Center for Precision Genome Editing and Genetic Technologies for Biomedicine of the Pirogov Russian National Research Medical University (Moscow, Russia) for the opportunity to use the molecular biology technologies.

Funding: the study was supported by the Ministry of Science and Higher Education of the Russian Federation, project ID RFMEFI61719X0056.

Compliance with ethical standards: the study was carried out in accordance with the World Medical Association Declaration of Helsinki.

$\bowtie$ Correspondence should be addressed: Diana V. Maltseva

Vavilova, 7, Moscow, 117321; dmaltseva@gmail.com

Received: 09.11.2020 Accepted: 01.12.2020 Published online: 16.12.2020

DOI: $10.24075 /$ brsmu.2020.078

\section{ИЗБИРАТЕЛЬНОЕ ИЗМЕНЕНИЕ ЭКСПРЕССИИ $\alpha$-СУБЪЕДИНИЦ ИНТЕГРИНОВ В КЛЕТКАХ КИШЕЧНОГО ЭПИТЕЛИЯ САСО-2 ПРИ ГИПОКСИИ В УСЛОВИЯХ МИКРОЦИРКУЛЯЦИИ}

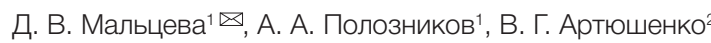

${ }^{1}$ Национальный исследовательский университет «Высшая школа экономики», Москва, Россия

${ }^{2}$ Art photonics $\mathrm{GmbH}$, Берлин, Германия

Кишечный эпителий постоянно находится в условиях физиологической гипоксии. Дополнительная тканевая гипоксия способна приводить К нарушению его функций и является признаком активного воспалительного процесса. В исследованиях in vitro значительную роль играют условия культивирования, поскольку в свою очередь могут влиять на свойства клеток. Целью работы было провести оценку экспрессии интегриновых рецепторов в клетках аденокарциномы толстого кишечника человека Сасо-2 при моделировании условий гипоксии хлоридом кобальта (II) и микроциркуляции. С помощью транскриптомного анализа обнаружено значимое увеличение экспрессии генов $\alpha 2-$ и $\alpha 5$-субъединиц интегриновых рецепторов ITGA2 и ITGA5 в условиях гипоксии и уменьшение ITGA5 при инкубировании в микрофлюидном чипе. Экспрессия $\beta$-субъединиц при этом не изменилась. При анализе микроРНК-транскриптомов выявлено уменьшение экспрессии микроРHK hsa-miR-766-3р и hsa-miR-23b-5p. В число валидированных мишеней обеих микроРНК входит мРНК гена ITGА5. Показано, что микроциркуляция позволяет создать для энтероцитов кишечника условия культивирования, более близкие к физиологическим. Представлено обсуждение возможного биологического значения выявленных изменений экспрессии профиля интегринов и роли микроциркуляции.

Ключевые слова: гипоксия, интегрины, микроРНК, МРНК, микрофлюидный чип, протеом, кишечная микробиота, Сасо-2

Благодарности: авторы выражают благодарность Центру коллективного пользования «Протеом человека» (ИБМХ) за возможность использования оборудования для анализа протеома, Центру высокоточного редактирования и генетических технологий для биомедицины РНИМУ им. Н. И. Пирогова (Москва, Россия) за возможность использования молекулярно-генетических технологий.

Финансирование: результаты получены при финансовой поддержке Российской Федерации в лице Министерства образования и науки. Уникальный идентификатор проекта RFMEFI61719X0056.

Вклад авторов: Д. В. Мальцева - работа с культурой клеток, молекулярно-биологические исследования, анализ данных, подготовка рукописи статьи; А. А. Полозников - обработка данных протеомного и транскриптомного анализа, биоинформатический анализ, функциональный анализ генов, статистический анализ, подготовка рукописи статьи, организация исследования; В. Г. Артюшенко - обсуждение результатов исследования, рецензирование рукописи статьи.

Соблюдение этических стандартов: исследование проведено в соответствии с требованиями Хельсинкской декларации Всемирной медицинской ассоциации.

$\bowtie$ Для корреспонденции: Диана Васильевна Мальцева

ул. Вавилова, д. 7, г. Москва, 117321; dmaltseva@gmail.com

Статья получена: 09.11.2020 Статья принята к печати: 01.12.2020 Опубликована онлайн: 16.12.2020

DOI: $10.24075 /$ vrgmu.2020.078 
The intestinal epithelium normally exists in a state of physiological hypoxia due to the commensal bacteria metabolism [1]. However, pathological processes, including inflammatory diseases and tumors, result in additional tissue hypoxia [2]. Yet the dramatic alterations in transcriptome and structure of the intestinal epithelial cell surface could be observed [3], which may result in the most important intestinal epithelium functions impairment, including barrier function and differential absorption, as well as in impaired interaction with microbiota. Thus, the interest to studying the effect of hypoxia on the intestine function have rised constantly in recent years.

There are several approaches to experimental models of hypoxia in vitro: the use of gas mixtures with low oxygen concentration [4], or the use of hypoxia mimetic agents, which increase the intracellular concentration of $\mathrm{HIF}-1 \alpha$, the hypoxia-inducible transcription factor. Such hypoxia mimetic agents include oxyquinoline derivatives [5], $\mathrm{Fe}^{2+}$ chelators and dimethyloxalylglycine (DMOG) [4]. However, the most widely used hypoxia mimetic agent is cobalt chloride $\left(\mathrm{CoCl}_{2}\right)$ [6]. It is also used in the experimental models of intestines in vitro [7]. Cobalt chloride induces stabilization of factors HIF- $1 \alpha$ and $\mathrm{HIF}-2 \alpha$, which are normally rapidly degraded.

MicroRNA (miRNA) is a class of small (of about 22 nucleotides in length) non-coding RNAs responsible for posttranscriptional gene expression regulation [8]. About one half of mammalian miRNA genes are encoded in introns of other genes. Together with the Argonaute family proteins, miRNAs interact with complementary sites in the target mRNAs, usually by partial binding [8]. Generally, the effective interaction with mRNA requires complementarity to a minimal seed region (matching nucleotides 2-7/8 of the miRNA), although often there are some other matching nucleotides. The Argonaute proteins attract other protein complexes which promote translational repression and the target mRNA degradation. About $60 \%$ of all protein-coding genes are regulated by miRNAs. A good deal of evidence suggests the key role of miRNA in the broad range of pathophysiological processes, including the intracellular and intercellular interactions [9], cancer, bacterial and viral infections [10]. Thus, the human miRNA families hsa-let-7e / hsa-mir-125a и hsa-mir-141 / hsa-miR-200 have recently been reported, responsible for regulation of genes ACE2 and TMPRSS2 being a gateway for coronavirus infection [10].

The Caco-2 cell line is widely used in the experimental models of intestinal epithelial barrier in vitro [11]. This cell line was first derived from patient with colon adenocarcinoma. However, when cultured, the Caco-2 cells become differentiated and form the monolayer of polarized cells with prismatic phenotype, expressing a number of intestinal brush border enzymes and membrane transporters specific to small intestine epithelial cells [12]. The proteome analysis data indicate that the differentiated Caco-2 cells resemble the native intestinal epithelium [13]. Our study is focused on the effect of hypoxia on the intestinal epithelial cells' adhesive properties. Integrins play a vital part in adhesion. Integrins are a superfamily of transmembrane receptors responsible for interaction with the extracellular matrix components and the other cell's surface proteins (including those of bacterial cells). All integrins are heterodymers consisting of $\alpha$ - and $\beta$-subunits. The $18 \alpha-$ and $8 \beta$-subunits have been identified in mammals. In the Caco- 2 cells the major subunits include $\alpha-2,5, \vee$ and $\beta-1$, 3,4 subunits [14], which is consistent with the integrin subunit expression profile of the human primary enterocytes [15]. The study was aimed to assess the Caco-2 cells' transcriptome and proteome alterations under the normal and hypoxic conditions, as well as to compare the results with alterations in the transcriptome of Caco-2 cells cultured in the microfluidic chip.

\section{METHODS}

\section{Caco-2 cell culture}

The immortalized human colorectal adenocarcinoma Caco-2 cells (Institute of Cytology RAS; St. Petersburg) were grown in the MEM culture medium (Gibco; USA) with the following supplements: 20\% fetal bovine serum (FBS, Gibco; USA), 1\% ( $\mathrm{v} / \mathrm{v})$ non-essential amino acids solution (Gibco; USA), penicillin $(100 \mathrm{U} / \mathrm{mL})$ and streptomycin $(100 \mu \mathrm{g} / \mathrm{mL})$ (Gibco; USA). The Caco-2 cells were cultured in the 6-well plates (Corning; USA) for 23 days up to the state of fully differentiated enterocytes. The culture medium was changed every 2-3 days. In order to simulate hypoxia, $\mathrm{CoCl}_{2}$ (Sigma-Aldrich; USA) was added to the culture media (Sigma-Aldrich; USA) to concentration of $300 \mu \mathrm{M}$ and incubated for $24 \mathrm{~h}$ in accordance with the previously reported algorithm [7]. After incubation, the cells were washed with the 1× DPBS (Gibco; USA), and lysed for transcriptome and proteome analysis using the previously reported method [16].

The the effect of hypoxia on the cell monolayer was assessed by impedance spectroscopy. Prior to plating of Caco-2 cells on the 96-well plates with membrane inserts (Corning; USA), all the wells were filled with culture medium ( $50 \mu$ into the upper chamber, $235 \mu$ into the lower chamber) and incubated for $1 \mathrm{~h}$ at a temperature of $37{ }^{\circ} \mathrm{C}$ in the $5 \% \mathrm{CO}_{2}$ atmosphere. Then the Caco- 2 cells were plated, approximately 5,600 cells per membrane insert, in the volume of $50 \mu \mathrm{L}$, and cultured for 23 days up to the state of fully differentiated enterocytes. The culture medium was changed every $2-3$ days. $\mathrm{CoCl}_{2}$ was added to the culture medium in order to induce hypoxia as described above.

In order to assess the influence of perfusion on the transcriptome, the Caco-2 cells were cultured in the microfluidic chip, which was designed during execution of the project "Study of Bacterial Adhesion in a Microfluidic Model of the Human Intestinal Barrier" supported by the Ministry of Science and Higher Education of the Russian Federation. The microfluidic chip is the flow system containing two cell culture wells, each of the wells is separated by membrane with the $0.4 \mu \mathrm{m}$ pore size.

First, the wells of microfluidic chip were coated with laminin 332 (Biolamina; Sweden). For that, $57 \mu \mathrm{L}$ of laminin 332 solution in DPBS $(0.01 \mathrm{mg} / \mathrm{mL})$ was added to the well and incubated for $24 \mathrm{~h}$ in the fridge at a temperature of $4{ }^{\circ} \mathrm{C}$. Then

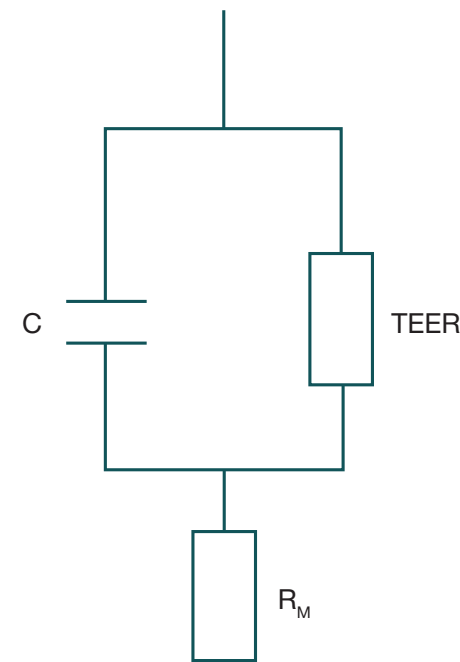

Fig. 1. Equivalent circuit used for calculation of the cell monolayer basic electrical parameters 
Table 1. Primers for qPCR. Nucleotide sequences are read from $5^{\prime}$ to $3^{\prime}$ end

\begin{tabular}{|l|c|c|}
\hline \multicolumn{1}{|c|}{ Gene } & Upstream primer & Downstream primer \\
\hline DDIT4 & gtttgaccgctccacgagcc & cgaagtcgggcaacgacacc \\
\hline EGLN1 & gacctgatacgccactgtaac & cggataacaagcaaccatg \\
\hline ITGA2 & gccaataatccaagagttgtgtt & tatttcttgcatattgaattgcttc \\
\hline ITGA5 & agagctacgggccaagctaa & ttccccataaagtttggtccac \\
\hline LDHA & atgggtgggtccttggggaa & tagcccaggatgtgtagccttga \\
\hline PFKFB3 & acgcctgtcgcttatggctg & ggcttttggtgggttcgggg \\
\hline SLC2A1 & gcagatgatgcgggagaagaaggt & ggtaatgaggaagccggtga \\
\hline SLC2A3 & tggtttattgtggccgaactc & aggggcacacaggatggctt \\
\hline VEGFA & tggcagaaggaggagggcag & gaagatggtgatgggatttc \\
\hline GAPDH & gaaggtgaaggtcggagtc & aagggacttcctgtaacaacgca \\
\hline ACTB & ctggaacggtgaaggtgaca & \\
\hline
\end{tabular}

the Caco-2 cells were detached from the substrate using the $0.25 \%$ trypsin-EDTA and the Hank's Balanced Salt Solution. After that the cells were resuspended in the culture medium and counted with the Countess Automated Cell Counter (Invitrogen; Germany). The cell suspension containing 20,000 Caco-2 cells in the volume of $50 \mu \mathrm{L}$ was added to each well of the chip, then the microfluidic chips were incubated in the cell incubator $\left(5 \% \mathrm{CO}_{2}, 37^{\circ} \mathrm{C}\right)$ for $2 \mathrm{~h}$. After the incubation the chip was connected to peristaltic pump to ensure perfusion in the $50 \mu \mathrm{L} / \mathrm{h}$ mode. The cells were cultured for 2 days in the cell incubator $\left(5 \% \mathrm{CO}_{2}, 37^{\circ} \mathrm{C}\right)$ with regular (at least twice a day) measurement of transepithelial electrical resistance in order to obtain the value of $350 \mathrm{Ohm} \cdot \mathrm{cm}^{2}$. The cells being in state of fully differentiated enterocytes were washed with the $1 \times$ DPBS (Gibco; USA) and lysed for transcriptome analysis using the previously reported method [16].

\section{Study of the collagen IV and laminin 332 membrane coating impact on the Caco-2 cell proliferation}

The surface of the Transwell membrane inserts of the Corning 96-well plate was coated with collagen IV and laminin 332. For that, $50 \mu \mathrm{L}$ of collagen IV solution in DPBS $(0.1 \mathrm{mg} / \mathrm{mL})$ or $57 \mu \mathrm{L}$ of laminin 332 solution in DPBS $(0.01 \mathrm{mg} / \mathrm{mL})$ was added to the appropriate inserts and incubated for $24 \mathrm{~h}$ at a temperature of $4^{\circ} \mathrm{C}$. Then the inserts were washed to remove the unbound extracellular matrix components, and the plate wells were filled with culture medium ( $50 \mu$ into the upper chamber, $235 \mu$ into the lower chamber). The plate was put in

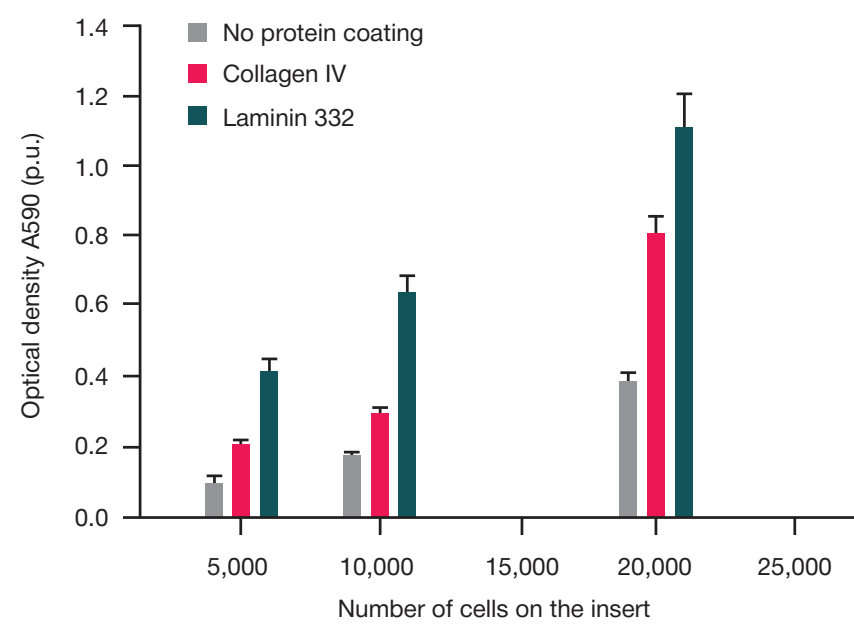

Fig. 2. Assessment of Caco-2 cells viability after $96 \mathrm{~h}$ of growth on the membrane inserts with no coating, coated with collagen IV and coated with laminin 332 the cell incubator $\left(5 \% \mathrm{CO}_{2}, 37^{\circ} \mathrm{C}\right)$ and incubated for $1 \mathrm{~h}$. After incubation, the culture medium was removed from membrane inserts; the cell suspension containing $5,000,10,000$ or 20,000 cells was added to the membrane inserts and incubated in the cell incubator $\left(5 \% \mathrm{CO}_{2}, 37^{\circ} \mathrm{C}\right)$ for $96 \mathrm{~h}$. After cultivation, MTS reagent with a concentration of $0.5 \mathrm{mg} / \mathrm{mL}$ was added to the culture medium and incubated at a temperature of $37^{\circ} \mathrm{C}$ for $4 \mathrm{~h}$. Then the optical density was measured at a wavelength of $590 \mathrm{~nm}$.

\section{Impedance spectra measurement and calculation of electrical parameters}

The impedance spectra were measured in the frequency range of $40-20,000 \mathrm{~Hz}$ using the impedance spectroscopy measurement system (Bioclinicum; Russia) and the STX100C96 electrode (World Precision Instruments; USA) at room temperature. In order to obtain the average values of the electrical parameters, three distinct membrane inserts with cells were used. Calculation of the cell monolayer electrical parameters (transepithelial electrical resistance (TEER), capacity C, and monolayer resistance $\mathrm{R}_{\mathrm{M}}$ ) was performed using the CEISA impedance fitting software (Bioclinicum; Russia) and the cell monolayer equivalent circuit (Fig. 1). The further statistical analysis was carried out using the R 3.5 programming language and the RStudio graphical user interface. The statistical significance of the observed differences in the TEER values was evaluated by the two-way analysis of variance (ANOVA). The P values of less than 0.05 were regarded as statistically significant.

\section{Transcriptome analysis}

Transcriptome analysis was carried out using the Gene Chip Human Transcriptome Array 2.0 microarray for mRNA and the Gene Chip miRNA 4.0 microarray for miRNA (TermoFisher Scientific-Affymetrix; USA). RNA isolation, quality control and quantification were performed in accordance with the previously reported method [16]. The RNA integrity number $(\mathrm{RIN})$ values exceeded 9.5 in all studied samples. The cDNAs were synthesized from $500 \mathrm{ng}$ of isolated total RNA. Sample preparation, hybridization, microarray washing, staining and scanning were carried out in accordance with the manufacturer's instructions. The CEL files obtained by the microarray scanning were processed using the Transcriptome Analysis Console 2.0 software package (TermoFisher Scientific-Affymetrix; USA). Microarrays contained multiple probes designed to hybridize to different gene regions for each gene, which comprised the multiple probe set (probe set). The probe sets not corresponding to any of the known genes (un-annotated probe sets) were 
excluded from analysis. When assessing the gene expression, the threshold signal intensity was set at 6.0 on the Affymetrix logarithmic scale.

\section{Real-time PCR (qPCR)}

The GPCR was performed in accordance with the previously reported method [16]. The real-time PCR product accumulation detection was based on SYBR-Green I fluorescence. The ACTB and GAPDH transcripts were used as reference genes (average threshold cycle values: 25.3 and 23.4 respecively). The nucleotide sequences of primers (Syntol; Russia) are presented in Table 1.

\section{Caco-2 cells proteome analysis}

The Caco-2 cells sample preparation, total protein extraction, hydrolysis and the subsequent procedures were carried out in accordance with the previously reported method [16]. After trypsinolysis, the supernatant fraction was analysed using the Q Exactive HF mass spectrometer with nano-electrospray ionization (nESI) source operated in the positive ionization mode (Thermo Fisher Scientific; USA), with the emitter voltage of 2.1 $\mathrm{kV}$ and the capillary temperature of $240{ }^{\circ} \mathrm{C}$. The protein level quantification was performed using the Progenesis IQ software (Waters; USA) with default settings. The proteins were identified using the SearchGUI v.3.3.1 software and the HumanDB database (UniProt Release 2018_05) with the following search parameters: digestive enzyme trypsin, monoisotopic mass accuracy \pm 5 ppm, mass measurement accuracy on tandem MS/MS data (tandem mass spectrometry) $\pm 25 \mathrm{ppm}$, and the chance to skip one cleavage site. In order to assess the differentially expressed proteins, the raw data were analyzed with the MaxQuant 1.6 software (Max-Planck-Institute of Biochemistry; Germany) (iBAQ algorithm). The further data processing was carried out using the Perseus software and the R 3.5 programming language with the integrated development environment RStudio 1.1 (R-Tools Technology; USA). Student's $t$-test was used to determine the statistical significance of the differences observed.

\section{Statistical data processing}

The raw microarray data were normalized using the oligo package for the R programming language [17]. The data obtained were log2-transformed. Student's $t$-test was used for analysis of differential expression of genes and miRNA. The false discovery rate (FDR) was controlled using the BenjaminiHochberg method developed for the multiple hypotheses testing [18]. The miRNA false positive rate was evaluated using the previously reported algorithm [19].

Functional gene annotation was performed using the DAVID version 6.8 databases and algorithms [20]. The experimentally supported miRNA-target interactions were exported from the DIANA-TarBase version 8 database [21]. The miRNA-binding sites in the $3^{\prime}$-untranslated regions (3'-UTR) of miRNA targets were predicted with the miRWalk tool [22]. The miRIAD database was used to explore the intragenic miRNA and their host genes [23].

\section{RESULTS}

\section{Exposure to $\mathrm{CoCl}_{2}$ mimics hypoxia in Caco-2 cells and upregulates the integrin $\alpha$-subunits}

According to literary sources, coating of the membrane used for Caco-2 cell culture with extracellular matrix proteins, such as collagens and laminins [24], can greatly affect the rate of monolayer formation and cell differentiation. Therefore, when optimizing the microfluidic intestinal barrier model culture conditions, we assessed the effect of the collagen IV and laminin 332 membrane coating on the Caco-2 cell proliferation. The study was carried out using the Transwell Corning membrane inserts. Coating of membrane with laminin 332 more than doubled the Caco-2 cell proliferation (Fig. 2). Therefore, cell culture on the laminin 332-coated membrane was selected for further investigation.

In order to mimic hypoxia, the Caco-2 cells were exposed to $\mathrm{CoCl}_{2}$ (see "Methods"). The impact of hypoxia on the cell monolayer was assessed by impedance spectroscopy. Impedance spectroscopy allows one to measure the electrical impedance (total resistance to sinusoidal alternating current) as a function of the frequency of applied electrical current (see "Methods") [25]. The efficiency of impedance spectroscopy for such kind of research has been previously reported [25]. The average TEER values, both for hypoxia and normoxia, are above 3,000 Ohm (corresponds to resistivity of $429 \mathrm{Ohm} \cdot \mathrm{cm}^{2}$ ). The TEER values depend both on the intracellular resistance resulting from the state of transmembrane channels responsible for transport of ions, and the state of tight junctions responsible for paracellular resistance. For example, it is known that the TEER values rapidly decrease with decreasing concentration of calcium in the medium, since the calcium ions are essential for maintenance of the tight junctions' normal structure. On the other hand, cell death results in the broken integrity of the membrane and the significantly decreased intracellular resistance. High TEER values observed throughout the experiment are the indication of intact tight junctions and lack of severe cytotoxicity resulting in cell death (Fig. 3).

Analysis of transcriptome for the treated and reference cells was carried out using the Affymetrix microarrays (TermoFisher Scientific-Affymetrix; USA). The significantly increased expression of genes involved in response to hypoxia in accordance with [26] was detected in samples exposed to $\mathrm{CoCl} 2$, the alterations revealed were validated using GPCR (Table 2). The significant alterations of expression (twofold or more; FDR $<0.05$ ) were detected in 165 genes. The functional annotation of genes using the DAVID databases and algorithms [20] showed the significant enrichment of the HIF-1 signalling pathway (KEGGpathway hsa04066), mediating the response to hypoxia (Table 3). Functional annotation revealed no enrichment of antioxidant

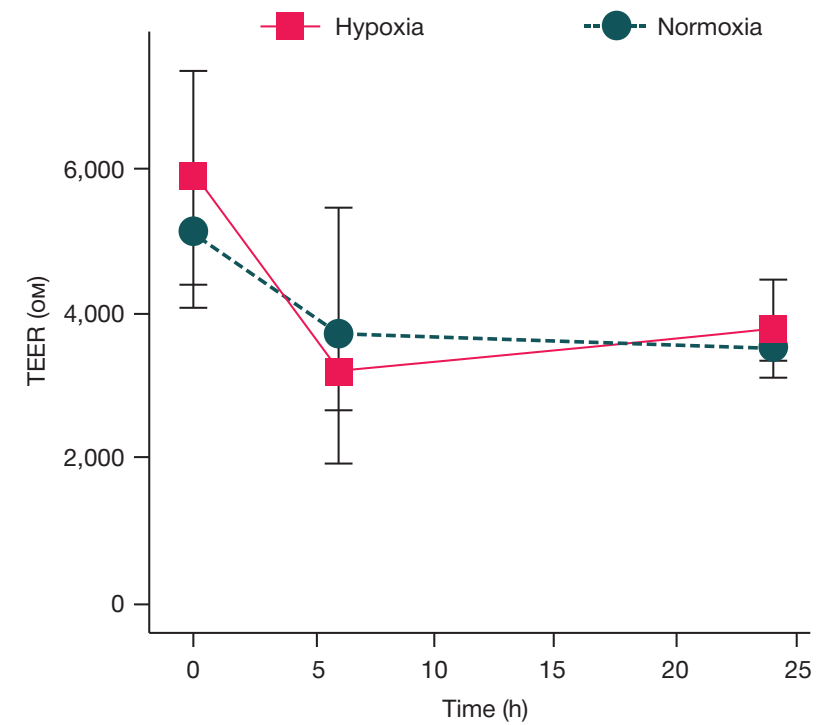

Fig. 3. Transepithelial electrical resistance (TEER) vs. time for normoxia and hypoxia 
Table 2. Differential expression of genes involved in response to hypoxia*

\begin{tabular}{|l|c|c|}
\hline \multirow{2}{*}{ Gene } & qPCR & Microarrays \\
\cline { 2 - 3 } & Expression change $^{\star \star}$ & Expression change $^{\star \star}$ \\
\hline DDIT4 & 2.7 & 2.4 \\
\hline EGLN1 & 3.4 & 2.7 \\
\hline LDHA & 4 & 2.0 \\
\hline PFKFB3 & 4.3 & 2.1 \\
\hline SLC2A1 & 2.1 & 3.1 \\
\hline SLC2A3 & 6.1 & 3.0 \\
\hline VEGFA & 2.4 & 1.4 \\
\hline
\end{tabular}

Note: * — the list of genes involved in response to hypoxia was formed based on the previously reported results [26]; ${ }^{\star *}$ — the ratio of expression levels (expressed as arbitrary units) under conditions of hypoxia simulation to reference samples ( $p<0.05$ for qPCR and microarrays). The expression of all listed genes increased under hypoxia-mimicking conditions compared to reference samples.

defence genes (GO: 0016209, antioxidant activity). Mass spectrometry of proteome for the treated and reference cells failed to detect the significant uncrease in the level of the following four proteins encoded by the HIF-1 signalling pathway genes: ENO2 by 19.6, HMOX1 by $29.1, P D K 1$ by 2.8 , and SLC2A1 by 2.2 times respectively. Proteome analysis revealed the total of 120 proteins, the expression of which significantly changed under hypoxia-mimicking conditions.

Comparison of the $\mathrm{CoCl}_{2}$-treated and reference cells' transcriptomes revealed the significantly increased expression of two genes encoding the integrin $\alpha$-subunits: under hypoxiamimicking conditions the expression of ITGA2 increased by 3.2 times $(p=0.02)$, and the expression of ITGA5 increased by 1.9 times $(p=0.0088)$. The alterations were validated using QPCR: the expression of ITGA2 and ITGA5 increased by 3.5 and 2.0 times respectively. No expression increase was observed for genes encoding $\beta$-subunits. During the proteome analysis, among all $\beta$-subunits only the $\beta 1$ - and $\beta 4$-subunits were detected, and there were no alterations in expression of those under hypoxia-mimicking conditions. In Caco-2 cells, these two subunits made up more than $90 \%$ of the total $\beta$-subunits number [14]. No $\alpha$-subunits were detected in the proteome, which could be due to insufficient analysis sensitivity. Furthermore, it had been shown before that the levels of $\alpha 2$ - and $\alpha 5$-subunits in the Caco-2 cells were 10 and 100 times lower than the level of $\beta 1$-subunits [14]. It's important that when growing the Caco-2 cells in the microfluidic chip, the expression of ITGA5, on the contrary, decreased by 2.1 times. The 1.6-fold decrease in the expression of gene LAMA1 encoding the normally abscent in the healthy gut laminin $\alpha 1$ chain was observed. This is evidence of the conditions closer to physiological established in the microfluidic chip. It should be noted that no significant alterations in genes involved in Table 3. Differential expression of genes involved in HIF-1 signalling pathway response to hypoxia and $\mathrm{HIF-1}$ signalling pathway compared to static condition have been revealed.

\section{Altered ITGA5 expression is associated with alterations in the regulatory miRNAs' expression}

To explore the possible cause of the ITGA2 and ITGA5 integrin expression alteration in response to hypoxia simulation, we analyzed miRNAs involved in regulation of these genes. Using the Affymetrix miRNA microarrays, the miRNA-transcriptomes of the $\mathrm{CoCl}_{2}$-treated and reference cells were assayed. Expression of nine miRNAs significantly changed under hypoxia-mimicking conditions. Of those two miRNAs, hsa-miR-23b-5p and hsamiR-766-3p, turned out to be the experimentally validated ITGA5 gene expression regulators $[27,28]$. In the hypoxic state the expression of those decreased by 2.2 and 2.1 times respectively $(p=0.046)$, which was opposite to the expression alteration of their target gene ITGA5.

Analysis of the discussed miRNAs binding to $3^{\prime}-U T R$ of the ITGA5 mRNA showed that both miRNAs were perfectly complementary to the target mRNA in the seed region (nucleotides 2-7/8 of miRNA) (Fig. 4). Perfect complementarity to the seed region is essential for efficient interaction between miRNA and mRNA. Moreover, both miRNAs are able to pair with the ITGA5 mRNA outside the seed region, which further increases the strength of binding (see Fig. 4).

Genes of both miRNAs are located in introns: hsa-miR-23b$5 p$ is located in the intron of gene AOPEP, and hsa-miR-766-3p is located in the intron of gene SEPTIN6. It should be noted that under conditions of hypoxia simulation no significant alterations in the listed hosting genes' expression have been detected. This may indicate that these miRNAs have independent transcription start sites, which have been previously found in many intronic miRNAs [29].

\begin{tabular}{|l|c|c|c|}
\hline \multicolumn{1}{|c|}{ Gene } & Expression change* & FDR \\
\hline PFKFB3 & 2.1 & 0.00016 & 0.0038 \\
\hline ENO2 & 3.0 & 0.00028 & 0.0043 \\
\hline HMOX1 & 2.5 & 0.0053 & 0.012 \\
\hline HK2 & 3.8 & 0.0077 & 0.013 \\
\hline EGLN1 & 2.7 & 0.014 & 0.018 \\
\hline PDK1 & 3.9 & 0.015 & 0.019 \\
\hline ENO1 & 2.3 & 0.018 & 0.022 \\
\hline SLC2A1 & 3.1 & 0.019 & 0.022 \\
\hline
\end{tabular}

Note: * 一 the ratio of expression levels (expressed as arbitrary units) under conditions of hypoxia simulation to reference samples; the results have been obtained using the microarray transcriptome analysis. 


\section{DISCUSSION}

The increased expression of genes involved in the HIF-1 signalling pathway was detected under hypoxic conditions simulated by exposure of colon adenocarcinoma Caco-2 cells to cobalt (II) chloride. The results obtained were consistent with literary data on the transcriprome alterations due to treatment of Caco-2 [30] and Caki-1 [31] cell lines with cobalt (II) chloride.

Hypoxia modeling has revealed the significantly increased expression of genes ITGA2 and ITGA5. These genes encode the integrin receptor $\alpha 2$ - and $\alpha 5$-subunits. Since no significant alterations of $\beta$-subunits have been detected, it can be assumed that the proportion of receptors containing $\alpha 2$ - and $\alpha 5$-subunits have increased under hypoxic conditions. We discovered that in the static Caco-2 cell culture the expression of ITGA5 was 2.1 times higher compared to cell culture in the microfluidic chip. Microcirculation brings the cell culture conditions closer to physiological conditions and increases the nutrient supply. Thus, alterations in the integrin receptor expression profile (higher proportion of $\alpha 2$ - and $\alpha 5$-subunits) may be the Caco-2 cells' response to the growth conditions deterioration. During the study we have discovered the potential regulators of ITGA2 and ITGA5 expression, the hsa-miR-23b-5p and hsa-miR766-3p miRNAs. The expression of those decreased under hypoxic conditions. In should be noted that in addition to the listed miRNA activity there may be cofactors promoting the expression of ITGA2 and ITGA5, for example, transcription factors involved in regulation of the discussed genes, which are also found to have altered expression levels.

The existing literature reports little information on the two identified miRNAs. Thus, it is known that the hsa-miR-766-3p downregulation results in increased proliferative activity of renal cell carcinoma cells [32] and hepatocellular carcinoma aggression [33]. Downregulation of hsa-miR-23b-5p results in increased proliferation and migration of the lung adenocarcinoma cells [34].

In order to become a receptor, integrin chains must form an $\alpha \beta$-heterodymer. In the intestinal epithelial cells, one of the major partners for $\alpha 2$ - and $\alpha 5$-chains is $\beta 1$-chain. The main ligands of the $\alpha 2 \beta 1$ integrin receptor are laminin, collagen and epithelial cadherin, and the receptor $\alpha 5 \beta 1$ binds to fibronectin [35]. These proteins, in turn, function as ligands for bacterial adhesins. For example, the YadA adhesin found on the outer membrane of the gram-negative bacteria Yersinia pseudotuberculosis and Yersinia enterocolitica (zoonotic bacterial pathogens causing pseudotuberculosis and yersiniosis) binds to collagen, laminin and fibronectin [36]. Furthermore, invasin, the protein of the outer membrane of the Yersenia genus pathogenic bacteria,

\section{hsa-miR-23b-5p \\ 3' TTTAGTCGTACGGTCCTTGGGT 5 | | | | | | || || \\ 5' TCTGGAGTTGATCTGGAACCCA 3' ITGA5}

\author{
hsa-miR-766-3p \\ 3' CGACTCCGACACCCCGACCTCA 5 \\ | I I| II| IIIIII| \\ 5' GATCCAGCCTGGGGTCTGGAGT 3' \\ ITGA5
}

Fig. 4. Hsa-miR-23b-5p and hsa-miR-766-3p miRNA binding sites for $3^{\prime}-U T R$ of ITGA5 mRNA

selectively binds the $\beta 1$ family integrin receptors, which results in translocation of bacteria across the epithelial layer [37]. It should be noted that in one of the studies simulation of hypoxia using DMOG was associated with a lower sensitivity of Caco-2 cells grown on plastic to Yersinia enterocolitica [38], which, according to the authors, was due to lower expression of integrin $\beta 1$-chain. In our study, no alterations in the integrin $\beta 1$-chain expression in cells grown on the permeable membrane insert were observed. This seems to indicate the importance of cell culture conditions used in such experiments. However, the influence of the specific hypoxia mimetic agents cannot be excluded.

Thus, the intestinal epithelial cells hypoxia, insufficient nutrient supply and excess metabolic waste result in altered integrin receptor expression profile, which may contribute to increased susceptibility to a number of bacterial pathogens. Hsa-miR-23b-5p and hsa-miR-766-3p miRNAs may function as regulators of the discussed process.

\section{CONCLUSION}

The use of cobalt (II) chloride made it possible to simulate hypoxia in the Caco-2 cell line. Transcriptome analysis revealed activation of key HIF-1 signalling pathway components, as well as alterations of the integrin expression profile in the intestinal epithelial cells. The discussed process could be regulated by the hsa-miR-23b-5p and hsa-miR-766-3p miRNAs, the expression of which inder hypoxic conditions decreased by 2.2 and 2.1 times respectively. Microcirculation has the opposite effect on the expression of ITGA5 and has no effect on the HIF-1 signalling pathway genes' expression.

\section{References}

1. Bartfeld S. Modeling infectious diseases and host-microbe interactions in gastrointestinal organoids. Dev Biol. Academic Press; 2016; 420 (2): 262-70.

2. Cummins EP, Crean D. Hypoxia and inflammatory bowel disease. Microbes Infect. Elsevier Masson; 2017; 19 (3): 210-21.

3. Ward JBJ, Keely SJ, Keely SJ. Oxygen in the regulation of intestinal epithelial transport. J Physiol. John Wiley \& Sons, Ltd: 2014; 592 (12): 2473-89.

4. Pavlacky J, Polak J. Technical feasibility and physiological relevance of hypoxic cell culture models. Front Endocrinol (Lausanne). Frontiers; 2020; 11: 57.

5. Poloznikov AA, Zakhariants AA, Nikulin S V, Smirnova NA, Hushpulian DM, Gaisina IN, et al. Structure-activity relationship for branched oxyquinoline HIF activators: Effect of modifications to phenylacetamide "tail". Biochimie. 2017; 133: 74-9.

6. Muñoz-Sánchez J, Chánez-Cárdenas ME. The use of cobalt chloride as a chemical hypoxia model. J Appl Toxicol. 2019; 39 (4): 556-70.

7. Lopez-Sánchez LM, Jimenez C, Valverde A, Hernandez V, Peñarando J, Martinez $\mathrm{A}$, et al. $\mathrm{CoCl} 2$, a mimic of hypoxia, induces formation of polyploid giant cells with stem characteristics in colon cancer. Maki CG, editor. PLoS One. Public Library of Science; 2014; 9 (6): e99143.

8. Makarova JA, Shkurnikov MU, Wicklein D, Lange T, Samatov TR, Turchinovich AA, et al. Intracellular and extracellular microRNA: An update on localization and biological role. Prog Histochem Cytochem. Urban \& Fischer; 2016; 51 (3-4): 33-49.

9. Turchinovich A, Samatov TR, Tonevitsky AG, Burwinkel B. 
Circulating miRNAs: cell-cell communication function? Front Genet. 2013; 4 (June): 119.

10. Nersisyan S, Shkurnikov M, Turchinovich A, Knyazev E, Tonevitsky A. Integrative analysis of miRNA and mRNA sequencing data reveals potential regulatory mechanisms of ACE2 and TMPRSS2. PLOS One. 2020; 15 (7 July).

11. Sakharov D, Maltseva D, Knyazev E, Nikulin S, Poloznikov A, Shilin S, et al. Towards embedding Caco-2 model of gut interface in a microfluidic device to enable multi-organ models for systems biology. BMC Syst Biol. BioMed Central; 2019; 13 (S1): 19.

12. Shah $P$, Jogani V, Bagchi T, Misra A. Role of Caco-2 cell monolayers in prediction of intestinal drug absorption. Biotechnol Prog. American Chemical Society (ACS); 2006; 22 (1): 186-98.

13. Lenaerts K, Bouwman FG, Lamers WH, Renes J, Mariman EC. Comparative proteomic analysis of cell lines and scrapings of the human intestinal epithelium. BMC Genomics. BioMed Central; 2007; 8 (1): 91

14. Ölander $M$, Wiśniewski JR, Matsson $P$, Lundquist $P$, Artursson $P$. The proteome of filter-grown Caco-2 cells with a focus on proteins involved in drug disposition. J Pharm Sci. Elsevier; 2016; 105 (2): 817-27.

15. Beaulieu J-F. Integrins and human intestinal cell functions [Internet]. Front Biosci. 1999

16. Maltseva D, Raygorodskaya M, Knyazev E, Zgoda V, Tikhonova O, Zaidi S, et al. Knockdown of the $\alpha 5$ laminin chain affects differentiation of colorectal cancer cells and their sensitivity to chemotherapy. Biochimie. Elsevier; 2020; 174: 107-16.

17. Carvalho BS, Irizarry RA. A framework for oligonucleotide microarray preprocessing. Bioinformatics. Oxford Academic; 2010; 26 (19): 2363-7.

18. Yoav $\mathrm{B}$, Yosef $\mathrm{H}$. Controlling the false discovery rate: A practical and powerful approach to multiple testing. J R Stat Soc. 1995; 57 (1): 289-300.

19. Nersisyan S, Shkurnikov M, Poloznikov A, Turchinovich A, Burwinkel B, Anisimov N, et al. A post-processing algorithm for miRNA microarray data. Int $\mathrm{J}$ Mol Sci. Multidisciplinary Digital Publishing Institute; 2020; 21 (4): 1228.

20. Huang DW, Sherman BT, Lempicki RA. Systematic and integrative analysis of large gene lists using DAVID bioinformatics resources. Nat Protoc. Nature Publishing Group; 2009; 4 (1): 44-57.

21. Karagkouni D, Paraskevopoulou MD, Chatzopoulos S, Vlachos IS, Tastsoglou S, Kanellos I, et al. DIANA-TarBase v8: a decade-long collection of experimentally supported miRNA-gene interactions. Nucleic Acids Res. Oxford Academic; 2018; 46 (D1): D239-45.

22. Sticht C, De La Torre C, Parveen A, Gretz N. miRWalk: An online resource for prediction of microRNA binding sites. Campbell $\mathrm{M}$, editor. PLoS One. Public Library of Science; 2018; 13 (10): e0206239.

23. Hinske LC, França GS, Torres HAM, Ohara DT, Lopes-Ramos CM, Heyn J, et al. miRIAD - integrating microRNA inter- and intragenic data. Database. Oxford Academic; 2014; 2014.

24. Basson MD, Modlin IM, Madri JA. Human enterocyte (Caco-2) migration is modulated in vitro by extracellular matrix composition and epidermal growth factor. J Clin Invest. American Society for

\section{Литература}

1. Bartfeld S. Modeling infectious diseases and host-microbe interactions in gastrointestinal organoids. Dev Biol. Academic Press; 2016; 420 (2): 262-70.

2. Cummins EP, Crean D. Hypoxia and inflammatory bowel disease. Microbes Infect. Elsevier Masson; 2017; 19 (3): 210-21.

3. Ward JBJ, Keely SJ, Keely SJ. Oxygen in the regulation of intestinal epithelial transport. J Physiol. John Wiley \& Sons, Ltd; 2014; 592 (12): 2473-89.

4. Pavlacky J, Polak J. Technical feasibility and physiological relevance of hypoxic cell culture models. Front Endocrinol (Lausanne). Frontiers; 2020; 11: 57.

5. Poloznikov AA, Zakhariants AA, Nikulin S V, Smirnova NA, Hushpulian DM, Gaisina IN, et al. Structure-activity relationship for branched oxyquinoline HIF activators: Effect of modifications to phenylacetamide "tail". Biochimie. 2017; 133: 74-9.
Clinical Investigation; 1992; 90 (1): 15-23.

25. Gerasimenko T, Nikulin S, Zakharova G, Poloznikov A, Petrov V, Baranova A, et al. Impedance spectroscopy as a tool for monitoring performance in 3D models of epithelial tissues. Front Bioeng Biotechnol. Frontiers; 2020; 7: 474.

26. Benita $Y$, Kikuchi H, Smith AD, Zhang MQ, Chung DC, Xavier RJ. An integrative genomics approach identifies Hypoxia Inducible Factor-1 (HIF-1)-target genes that form the core response to hypoxia. Nucleic Acids Res. 2009; 37 (14): 4587-602.

27. Karginov F V, Hannon GJ. Remodeling of Ago2-mRNA interactions upon cellular stress reflects miRNA complementarity and correlates with altered translation rates. Genes Dev. Cold Spring Harbor Laboratory Press; 2013; 27 (14): 1624-32.

28. Balakrishnan I, Yang X, Brown J, Ramakrishnan A, Torok-Storb B, Kabos $P$, et al. Genome-wide analysis of miRNA-mRNA interactions in marrow stromal cells. Stem Cells. John Wiley \& Sons, Ltd; 2014; 32 (3): 662-73.

29. Steiman-Shimony A, Shtrikman O, Margalit H. Assessing the functional association of intronic miRNAs with their host genes. RNA. Cold Spring Harbor Laboratory Press; 2018; 24 (8): 991-1004.

30. Calvo-Anguiano G, Lugo-Trampe J, Camacho A, Said-Fernández S, Mercado-Hernández R, Zomosa-Signoret V, et al. Comparison of specific expression profile in two in vitro hypoxia models. Exp Ther Med. Spandidos Publications; 2018; 15 (6): 4777-84.

31. Zhigalova N, Artemov A, Mazur AM, Prokhortchouk EB. Transcriptome sequencing revealed differences in the response of renal cancer cells to hypoxia and $\mathrm{CoCl}_{2}$ treatment. F1000Research. F1000 Research Limited; 2015; 4: 1518.

32. Chen C, Xue S, Zhang J, Chen W, Gong D, Zheng J, et al. DNAmethylation-mediated repression of miR-766-3p promotes cell proliferation via targeting SF2 expression in renal cell carcinoma. Int J Cancer. John Wiley \& Sons, Ltd; 2017; 141 (9): 1867-78.

33. You Y, Que K, Zhou Y, Zhang Z, Zhao X, Gong J, et al. MicroRNA766-3p inhibits tumour progression by targeting Wnt3a in hepatocellular carcinoma. Moleucles and Cells. Korean Society for Molecular and Cellular Biology; 41 (9): 830-41.

34. Hu G, Wang C, Wang H, Wang Y, Hu S, Cao Z, et al. Long noncoding RNA CCAT2 functions as a competitive endogenous RNA to regulate FOXC1 expression by sponging miR-23b-5p in lung adenocarcinoma. J Cell Biochem. John Wiley \& Sons, Ltd; 2019; 120 (5): 7998-8007.

35. Takada Y, YeX, Simon S. The integrins. Genome Biol. 2007; 8 (5): 215.

36. Heise T, Dersch P. Identification of a domain in Yersinia virulence factor YadA that is crucial for extracellular matrix-specific cell adhesion and uptake. Proc Natl Acad Sci U S A. National Academy of Sciences; 2006; 103 (9): 3375-80.

37. Isberg RR, Leong JM. Multiple $\beta 1$ chain integrins are receptors for invasin, a protein that promotes bacterial penetration into mammalian cells. Cell. Cell Press; 1990; 60 (5): 861-71.

38. Zeitouni NE, Dersch P, Naim HY, von Köckritz-Blickwede M. Hypoxia decreases invasin-mediated Yersinia enterocolitica internalization into Caco-2 cells. Karhausen J, editor. PLoS One. Public Library of Science; 2016; 11 (1): e0146103.

6. Muñoz-Sánchez J, Chánez-Cárdenas ME. The use of cobalt chloride as a chemical hypoxia model. J Appl Toxicol. 2019; 39 (4): 556-70.

7. Lopez-Sánchez LM, Jimenez C, Valverde A, Hernandez V, Peñarando J, Martinez A, et al. CoCl2, a mimic of hypoxia, induces formation of polyploid giant cells with stem characteristics in colon cancer. Maki CG, editor. PLoS One. Public Library of Science; 2014; 9 (6): e99143.

8. Makarova JA, Shkurnikov MU, Wicklein D, Lange T, Samatov TR, Turchinovich AA, et al. Intracellular and extracellular microRNA: An update on localization and biological role. Prog Histochem Cytochem. Urban \& Fischer; 2016; 51 (3-4): 33-49.

9. Turchinovich A, Samatov TR, Tonevitsky AG, Burwinkel B. Circulating miRNAs: cell-cell communication function? Front Genet. 2013; 4 (June): 119. 
10. Nersisyan S, Shkurnikov M, Turchinovich A, Knyazev E, Tonevitsky A. Integrative analysis of miRNA and mRNA sequencing data reveals potential regulatory mechanisms of ACE2 and TMPRSS2. PLoS One. 2020; 15 (7 July).

11. Sakharov D, Maltseva D, Knyazev E, Nikulin S, Poloznikov A, Shilin S, et al. Towards embedding Caco-2 model of gut interface in a microfluidic device to enable multi-organ models for systems biology. BMC Syst Biol. BioMed Central; 2019; 13 (S1): 19.

12. Shah $P$, Jogani $V$, Bagchi T, Misra A. Role of Caco-2 cell monolayers in prediction of intestinal drug absorption. Biotechnol Prog. American Chemical Society (ACS); 2006; 22 (1): 186-98.

13. Lenaerts K, Bouwman FG, Lamers WH, Renes J, Mariman EC. Comparative proteomic analysis of cell lines and scrapings of the human intestinal epithelium. BMC Genomics. BioMed Central; 2007; 8 (1): 91.

14. Ölander M, Wiśniewski JR, Matsson P, Lundquist P, Artursson P. The proteome of filter-grown Caco-2 cells with a focus on proteins involved in drug disposition. J Pharm Sci. Elsevier; 2016; 105 (2): 817-27.

15. Beaulieu J-F. Integrins and human intestinal cell functions [Internet]. Front Biosci. 1999.

16. Maltseva D, Raygorodskaya M, Knyazev E, Zgoda V, Tikhonova O, Zaidi $S$, et al. Knockdown of the $\alpha 5$ laminin chain affects differentiation of colorectal cancer cells and their sensitivity to chemotherapy. Biochimie. Elsevier; 2020; 174: 107-16.

17. Carvalho BS, Irizarry RA. A framework for oligonucleotide microarray preprocessing. Bioinformatics. Oxford Academic; 2010; 26 (19): 2363-7.

18. Yoav $\mathrm{B}$, Yosef $\mathrm{H}$. Controlling the false discovery rate: A practical and powerful approach to multiple testing. J R Stat Soc. 1995; 57 (1): 289-300.

19. Nersisyan S, Shkurnikov M, Poloznikov A, Turchinovich A, Burwinkel B, Anisimov N, et al. A post-processing algorithm for miRNA microarray data. Int $\mathrm{J}$ Mol Sci. Multidisciplinary Digital Publishing Institute; 2020; 21 (4): 1228.

20. Huang DW, Sherman BT, Lempicki RA. Systematic and integrative analysis of large gene lists using DAVID bioinformatics resources. Nat Protoc. Nature Publishing Group; 2009; 4 (1): 44-57.

21. Karagkouni D, Paraskevopoulou MD, Chatzopoulos S, Vlachos IS, Tastsoglou S, Kanellos I, et al. DIANA-TarBase v8: a decade-long collection of experimentally supported miRNA-gene interactions. Nucleic Acids Res. Oxford Academic; 2018; 46 (D1): D239-45.

22. Sticht C, De La Torre C, Parveen A, Gretz N. miRWalk: An online resource for prediction of microRNA binding sites. Campbell M, editor. PLoS One. Public Library of Science; 2018; 13 (10): e0206239.

23. Hinske LC, França GS, Torres HAM, Ohara DT, Lopes-Ramos CM, Heyn J, et al. miRIAD - integrating microRNA inter- and intragenic data. Database. Oxford Academic; 2014; 2014.

24. Basson MD, Modlin IM, Madri JA. Human enterocyte (Caco-2) migration is modulated in vitro by extracellular matrix composition and epidermal growth factor. J Clin Invest. American Society for Clinical Investigation; 1992; 90 (1): 15-23.
25. Gerasimenko T, Nikulin S, Zakharova G, Poloznikov A, Petrov V, Baranova A, et al. Impedance spectroscopy as a tool for monitoring performance in 3D models of epithelial tissues. Front Bioeng Biotechnol. Frontiers; 2020; 7: 474.

26. Benita Y, Kikuchi H, Smith AD, Zhang MQ, Chung DC, Xavier RJ. An integrative genomics approach identifies Hypoxia Inducible Factor-1 (HIF-1)-target genes that form the core response to hypoxia. Nucleic Acids Res. 2009; 37 (14): 4587-602.

27. Karginov F V, Hannon GJ. Remodeling of Ago2-mRNA interactions upon cellular stress reflects miRNA complementarity and correlates with altered translation rates. Genes Dev. Cold Spring Harbor Laboratory Press; 2013; 27 (14): 1624-32.

28. Balakrishnan I, Yang X, Brown J, Ramakrishnan A, Torok-Storb B, Kabos $P$, et al. Genome-wide analysis of miRNA-mRNA interactions in marrow stromal cells. Stem Cells. John Wiley \& Sons, Ltd; 2014; 32 (3): 662-73.

29. Steiman-Shimony A, Shtrikman O, Margalit H. Assessing the functional association of intronic miRNAs with their host genes. RNA. Cold Spring Harbor Laboratory Press; 2018; 24 (8): 991-1004.

30. Calvo-Anguiano G, Lugo-Trampe J, Camacho A, Said-Fernández S, Mercado-Hernández R, Zomosa-Signoret V, et al. Comparison of specific expression profile in two in vitro hypoxia models. Exp Ther Med. Spandidos Publications; 2018; 15 (6): 4777-84.

31. Zhigalova N, Artemov A, Mazur AM, Prokhortchouk EB. Transcriptome sequencing revealed differences in the response of renal cancer cells to hypoxia and $\mathrm{CoCl}_{2}$ treatment. F1000Research. F1000 Research Limited; 2015; 4: 1518.

32. Chen C, Xue S, Zhang J, Chen W, Gong D, Zheng J, et al. DNAmethylation-mediated repression of miR-766-3p promotes cell proliferation via targeting SF2 expression in renal cell carcinoma. Int J Cancer. John Wiley \& Sons, Ltd; 2017; 141 (9): 1867-78.

33. You Y, Que K, Zhou Y, Zhang Z, Zhao X, Gong J, et al. MicroRNA766-3p inhibits tumour progression by targeting Wnt3a in hepatocellular carcinoma. Moleucles and Cells. Korean Society for Molecular and Cellular Biology; 41 (9): 830-41.

34. Hu G, Wang C, Wang H, Wang Y, Hu S, Cao Z, et al. Long noncoding RNA CCAT2 functions as a competitive endogenous RNA to regulate FOXC1 expression by sponging miR-23b-5p in lung adenocarcinoma. J Cell Biochem. John Wiley \& Sons, Ltd; 2019; 120 (5): 7998-8007.

35. Takada Y, YeX, Simon S. The integrins. Genome Biol. 2007; 8 (5): 215.

36. Heise T, Dersch P. Identification of a domain in Yersinia virulence factor YadA that is crucial for extracellular matrix-specific cell adhesion and uptake. Proc Natl Acad Sci U S A. National Academy of Sciences; 2006; 103 (9): 3375-80.

37. Isberg RR, Leong JM. Multiple $\beta 1$ chain integrins are receptors for invasin, a protein that promotes bacterial penetration into mammalian cells. Cell. Cell Press; 1990; 60 (5): 861-71.

38. Zeitouni NE, Dersch P, Naim HY, von Köckritz-Blickwede M. Hypoxia decreases invasin-mediated Yersinia enterocolitica internalization into Caco-2 cells. Karhausen J, editor. PLoS One. Public Library of Science; 2016; 11 (1): e0146103. 